\title{
Impact of tobacco price and taxation on affordability and consumption of tobacco products in the South-East Asia Region: A systematic review
}

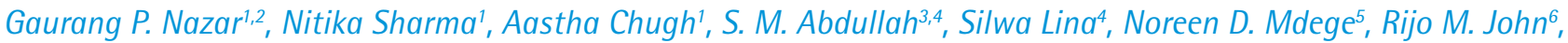 \\ Rumana Huque ${ }^{3,4}$, Linda Bauld ${ }^{7,8}$, Monika Arora ${ }^{1,2}$
}

\section{ABSTRACT}

INTRODUCTION The objective of the review was to study the impact of tobacco taxes or prices on affordability and/or consumption of tobacco products in WHO SouthEast Asia Region (SEAR) countries, overall and by socioeconomic status; and change in consumption of one tobacco product for a given change in price/tax on another tobacco product.

METHOds The searches were made in five databases (Medline, Embase, Cinahl, EconLit, Tobacconomics) using keywords such as 'tobacco', 'tax', 'price', 'impact' with their synonyms. Additionally, the first 100 articles through google search and e-reports from targeted sources were also reviewed. Studies illustrating the impact of prices/taxes on consumption/affordability of tobacco products in SEAR, in English and with no limitation on year, were included in the review. After two steps of screening, data from 28 studies were extracted using a structured and pre-tested data extraction form.

RESULTS Of the 28 studies, 12 studies reported an inverse association between price and consumption/affordability, while 11 studies reported no or positive association between price and consumption/affordability of tobacco products. Five studies had unclear interpretations. The majority of studies estimated that the less affluent group were more price responsive compared to the more affluent group. Some studies indicated increased consumption of one product in response to price rise of another product, although, the findings were inconsistent.

Conclusions The findings of our review support the use of tobacco tax and price measures as effective tools to address the tobacco epidemic. Our findings, however, also emphasize the importance of increasing tobacco product taxes and prices sufficiently to outweigh the effects of income growth, in order for the measures to be effective in reducing the affordability and consumption of tobacco products.

\author{
AFFILIATION \\ 1 Health Related Information \\ Dissemination Amongst \\ Youth, New Delhi, India \\ 2 Health Promotion Division, \\ Public Health Foundation of \\ India, Gurugram, India \\ 3 Department of Economics, \\ University of Dhaka, Dhaka, \\ Bangladesh \\ 4 ARK Foundation, Dhaka, \\ Bangladesh \\ 5 Department of Health \\ Sciences, University of York, \\ York, United Kingdom \\ 6 Rajagiri College of Social \\ Sciences, Kochi, India \\ 7 Usher Institute, University \\ of Edinburgh, Edinburgh, \\ United Kingdom \\ 8 SPECTRUM Consortium, \\ University of Edinburgh, \\ Edinburgh, United Kingdom \\ CORRESPONDENCE TO \\ Gaurang P. Nazar. Health \\ Related Information \\ Dissemination Amongst \\ Youth, B-5/94, Safdarjung \\ Enclave, First Floor, New \\ Delhi 110029, India. E-mail: \\ gaurang@hriday-shan.org \\ ORCID ID: https://orcid. \\ org/0000-0002-7025-2946 \\ KEYWORDS \\ tobacco, taxation, \\ affordability, Southeast Asia \\ Received: 4 April 2021 \\ Revised: 29 September 2021 \\ Accepted: 19 October 2021
}

\section{INTRODUCTION}

Tobacco taxes influence the price, affordability and demand of tobacco products ${ }^{1,2}$. Raising taxes on tobacco products is one of the most cost-effective measures for reducing the consumption of tobacco ${ }^{3-5}$. However, to be effective in reducing tobacco consumption, the 
tax increases need to result in increases in tobacco product prices that are sufficient to outweigh the effect of real income growth ${ }^{6}$. The change in affordability of tobacco products is an important determinant of the prevalence of use, especially in countries with rapid economic growth ${ }^{1,2}$. In addition, change in affordability of a specific tobacco product can affect the consumption of other tobacco products ${ }^{6}$. Hence, while the price elasticity of demand estimates are often used to represent the relative price response for the demand of tobacco products ceteris paribus ${ }^{7}$, affordability (i.e. the percentage of income required to buy specific units of a tobacco product) has been proposed as an alternative for evaluating the impact of tobacco-control fiscal policies ${ }^{8}$. The affordability of tobacco products adjusts for the consumer's purchasing power and is dependent on the income of consumers and price of tobacco products. A higher affordability index relative to a reference point indicates that tobacco products have become more expensive (i.e. less affordable) in relation to the income of consumers. As a result of the decrease in affordability, their consumption, in turn, is expected to decrease $\mathrm{e}^{9,10}$.

The price response of the consumption of tobacco products can be even more complicated in the World Health Organization defined South-East Asia Region (WHO-SEAR, hereafter referred to as SEAR), which has a myriad of challenges related to tobacco fiscal policies. SEAR countries like India, Bangladesh, and Indonesia, comprise the top-twenty global tobacco producers ${ }^{11}$. The wide variety of tobacco products, including smokeless tobacco and indigenous products, pose a significant challenge to levying and administering optimal levels of taxes on these products ${ }^{12}$. In addition, there are also wide socioeconomic disparities within this region in terms of tobacco use and income/earnings ${ }^{10,13-16}$. Only one (Thailand) out of the 11 SEAR countries has achieved the World Health Organization (WHO) bestpractice recommendation, that of a minimum $75 \%$ of the retail price of a pack of cigarettes ${ }^{17}$. However, in some SEAR countries, the percentage of the retail price of a pack of cigarettes that is excise tax is very low, for example $19 \%$ in Timor-Leste ${ }^{17}$.

In 2003, Guindon et al. ${ }^{18}$ provided a summary of nine studies that reported data on the impact of tobacco price or per capita income on tobacco consumption across six SEAR countries. They reported an overall reduction in tobacco consumption in response to its price increase and estimated price elasticities of -0.50 in the short-term and -0.70 in the long-term for tobacco products in this region ${ }^{18}$. The study also projected an increase in tobacco consumption due to an increase in income ${ }^{18}$. However, the study did not explore the price response of tobacco products on their consumption by socioeconomic status (SES) groups and cross price elasticities. A recent study, using global data from 169 countries estimated the price elasticity and affordability exclusively for cigarettes, by their income stratification [low- and middleincome country (LMIC) and high-income country (HIC) $]^{1}$. There are studies that have illustrated the impact of taxation on consumer behavior in general, and in other regions ${ }^{4,18,19}$.

Currently available reviews that are specific to the SEAR are old ${ }^{18}$, and need to be updated to incorporate more recent studies. Monitoring the affordability of cigarettes over time is important, and considered 'the optimal nominal anchor for tobacco tax policy ${ }^{\prime 17}$. Currently existing reviews that are specific to the SEAR also do not encompass the implications of change in price and consumption of tobacco products by SES ${ }^{18,20}$. In addition, studies that investigate the impact of price/tax on affordability of tobacco products in SEAR countries ${ }^{2,21-23}$ are yet to be reviewed. Hence, the aim of this study was to comprehensively investigate the impact of tobacco prices/taxes on the consumption (primary outcome) or affordability (secondary outcome) of tobacco products in SEAR countries. We also investigated the change in affordability or consumption of tobacco products in response to price/tax change by SES; and the change in consumption of one tobacco product for a given change in price/tax on another tobacco product (cross price elasticity).

\section{METHODS}

The systematic review followed the Cochrane guidelines ${ }^{24}$ and reported as per the Preferred Reporting Items for Systematic Reviews and Metaanalyses (PRISMA) guidelines ${ }^{25}$. The systematic review protocol was published in the International Prospective Register of Systematic Reviews (PROSPERO 2020, CRD42020133082) ${ }^{26}$.

\section{Eligibility criteria}

Studies specific to SEAR countries, illustrating the 
actual impact of prices/taxes on consumption/ affordability of tobacco products were eligible for inclusion. Narrative/systematic reviews and studies 'predicting' the impact of price change on the affordability/consumption of tobacco products were excluded from the review. We restricted eligible studies to those whose full articles were available in English. Multi-country studies, containing clear findings specific to SEAR countries were also included in the review. A detailed description of the eligibility criteria is provided in Table 1 .

\section{Search strategy}

The searches were made in April 2020 on five electronic databases - Medline, Cinahl, Econlit, Embase, and Tobacconomics, using keywords for names of different tobacco products, SEAR countries, tax, and price. We did not impose any limitations on the year. The search strategy used for each database is provided in the Supplementary file Tables S1-S5. We also checked the reference lists of studies that met the eligibility criteria; made a search on the Google search engine from which the first 100 articles were screened for inclusion in the review; and searched relevant websites such as WHO, South-East Asia Tobacco Control Alliance (SEATCA), International
Agency for Research on Cancer (IARC), and other United Nations (UN) organizations.

\section{Study selection}

The studies retrieved from searches were deduplicated using Mendeley reference management software $^{27}$. Each study was independently screened by two reviewers in two phases using a standardized study selection form, as per the pre-specified inclusion and exclusion criteria (Table 1 and Supplementary file Table S6). The form was piloted on 10 studies before it was used for study selection. The first phase involved title and abstract screening. Studies that were judged to be potentially eligible from their title and abstracts, or for which there was inadequate information to make an inclusion decision during the first screening phase, had their full texts screened in the second phase. Any disagreements were resolved through consensus and discussion with a third reviewer when required.

\section{Data extraction}

The included studies were imported to an open access, free web-based tool for systematic reviews, CADIMA (https://www.cadima.info/). An electronic data extraction form was used to extract data including

\section{Table 1. Eligibility criteria for the studies included in the review}

\begin{tabular}{|c|c|c|}
\hline Criteria & Characteristics & Status \\
\hline $\begin{array}{l}\text { Population/ } \\
\text { participants }\end{array}$ & $\begin{array}{l}\text { Studies from WHO Southeast Asia Region (SEAR) countries namely- Bangladesh, Bhutan, } \\
\text { Democratic People's Republic of Korea (DPRK), India, Indonesia, Maldives, Myanmar, Nepal, Sri } \\
\text { Lanka, Thailand and Timor-Leste }\end{array}$ & Included \\
\hline Intervention & $\begin{array}{l}\text { Tobacco price and taxation changes including specific excise, ad valorem tax, import/export duty, } \\
\text { value added tax, mixed-tax and surcharges/cess }\end{array}$ & Included \\
\hline Comparator & Irrespective of comparator or control group & NA \\
\hline \multicolumn{3}{|l|}{ Outcome } \\
\hline Primary & $\begin{array}{l}\text { Consumption (prevalence and/or frequency) of tobacco products } \\
\text { Affordability of tobacco products }\end{array}$ & Included \\
\hline Additional & $\begin{array}{l}\text { Affordability and change in consumption of tobacco products by socioeconomic status. } \\
\text { Percentage change in consumption of one tobacco product for a given change in price or tax on } \\
\text { other tobacco product. }\end{array}$ & Included \\
\hline Study design & $\begin{array}{l}\text { Cross-sectional } \\
\text { Case-control } \\
\text { Interrupted time series } \\
\text { Quantitative secondary data analysis } \\
\text { Narrative reviews } \\
\text { Econometric studies predicting the impact of price and tax changes on outcomes } \\
\text { Econometric studies not reflecting the impact of actual price and tax measures on outcomes } \\
\text { Systematic reviews }\end{array}$ & $\begin{array}{l}\text { Included } \\
\text { Included } \\
\text { Included } \\
\text { Included } \\
\text { Excluded } \\
\text { Excluded } \\
\text { Excluded } \\
\text { Excluded }\end{array}$ \\
\hline
\end{tabular}


study title, author, year of publication, population/ dataset characteristics, outcome and measures of effect (Supplementary file Table S7). For those studies reporting both the impact of 'predicted' price/tax rise on consumption/affordability of tobacco products, and the impact of 'actual' price/tax changes, only the parts reporting the impact of actual price/tax changes on consumption/affordability were included in the data extraction and synthesis (Table 1). The data extraction form was an adaptation of the Cochrane Collaboration's data extraction form for intervention reviews ${ }^{28}$, and it was pre-tested on three studies before use. Data extraction from each article was conducted independently by two reviewers on CADIMA.

\section{Study quality assessment}

The Crombie's I tool was modified and used for quality assessment of included studies ${ }^{29}$. The tool was pilot tested on three studies and minor adaptations made before use. The tool comprised nine items including whether the study objectives were clearly stated, the sample size calculation was clear and representative of the population, and validated methods/models for evaluating the outcomes had been used. The detailed Crombie's item list used in the review is given in Supplementary file Table S8. The score ranged 0-9. Studies with a score of $0-3$ were marked as 'low quality', 4-6 as 'moderate quality', and 7-9 as 'high quality $^{30}$. The quality assessment of each article was also conducted independently by two reviewers. Any disagreements were resolved through discussion or consultation with a third reviewer.

\section{Data synthesis}

Data from the included studies were narratively synthesized ${ }^{31}$ under the following three main themes: 1) The impact of tobacco tax/price on the consumption/affordability of tobacco products; 2 ) The impact of tobacco tax/price on the consumption/ affordability of tobacco products by SES; and 3) Cross price elasticity and consumption. Within these main themes, studies were further grouped according to the direction of the association between tax/price and affordability/consumption as follows: 1) Inverse association between tax/price and consumption/ affordability (i.e. where tax/price increases were associated with reductions in tobacco product consumption, or with the products becoming less affordable); 2) Positive or no association between tax/price and consumption/ affordability of tobacco products (i.e. where tax/price increases were associated with increases/no change in consumption of tobacco products, or increases/no change in the affordability of tobacco products); and 3) Unclear association (i.e. if the impact of taxes/prices on consumption/affordability of tobacco products was not clearly drawn from the study or the authors gave contradictory interpretations in the same study). We were expecting heterogeneity across the studies in terms of their methodology, population, settings and other geographical factors. Hence, we did not plan or conduct a meta-analysis as per our protocol ${ }^{26}$.

\section{RESULTS}

The literature searches resulted in 880 studies (Figure $1)$. Of these, 132 were duplicates and removed. After title and abstract screening of the remaining 748 articles, 74 studies were included for full-text screening. Among the 74 studies, 46 were excluded because of the following reasons: non-SEAR regions $(n=9)$, duplicates $(n=5)$, study design $(n=10)$, did not report any of the outcomes of interest $(n=11)$ and multiple reasons (i.e. not meeting more than one eligibility criterion) $(n=6)$. Five studies were also excluded due to the unavailability of full texts, even after contacting the authors. Twenty-eight studies were included in our review. The detailed characteristics of the included studies such as the title, author information, tobacco products, intervention and outcomes are provided in the Supplementary file Tables S9-S11. None of the included studies was funded by the tobacco industry.

\section{Overview of the studies}

The highest number of included studies were from India ( $n=9)$, followed by Bangladesh $(n=5)$, Indonesia $(n=3)$, Thailand $(n=3)$, Myanmar $(n=2)$, Sri Lanka $(\mathrm{n}=2)$, and Nepal $(\mathrm{n}=1)$ (Table 2). The remaining three studies covered more than one SEAR country (Table 2). The majority of studies $(n=25)$ involved quantitative secondary data analysis and the remaining $(n=3)$ were primary cross-sectional studies. Most studies used national-level surveys such as the Global Adult Tobacco Survey (GATS), Tobacco Control Policy Survey (TCP), International Tobacco Control South- 
Figure 1. PRISMA flow diagram of the selection phases of the studies

e-databases
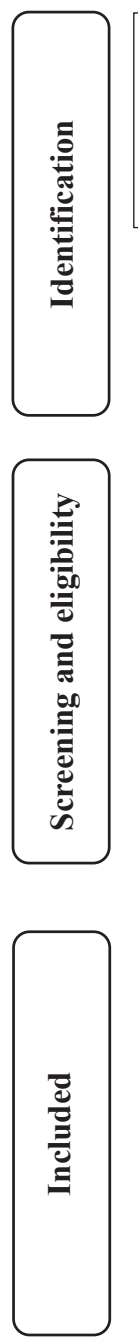

Targeted sources and Grey literature

First 100 searches on Google, other known published/online literature from World Health Organization (WHO), International Agency for Research on Cancer (IARC), Southeast Asia Tobacco Control Alliance (SEATCA), country-wise government websites and other United Nation (UN) agencies.

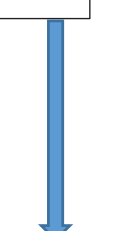

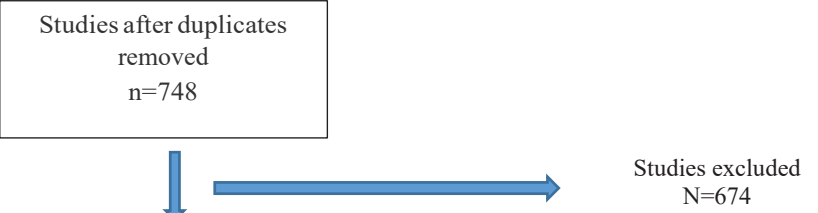

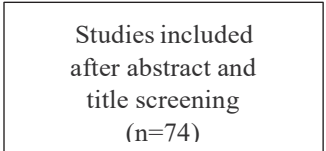

Studies excluded $=46$

Reasons for exclusion: Full text not available $=5$ Other region $=9$ Duplicates/(including Reports for which references were used) $=5$ Study designs $=10$ Different outcome/Outcomes based on assumption/future projections $=11$

Studies included in the systematic review $(\mathrm{n}=28)$

East Asia Survey (ITC), or government/international agency reports for consumption and pricing data, to calculate the affordability or price elasticity of tobacco products. Thirteen studies evaluated cigarettes or different variants and brands (including cheroots, hand-rolled cigarettes), two studies exclusively evaluated smokeless tobacco products and 13 studies evaluated multiple tobacco product types (e.g. bidis and cigarettes or smoked products with smokeless products). Of the 28 studies, 18 included information on our secondary outcomes. Around twenty studies reported the change in consumption of tobacco products, while six studies reported the change in affordability of tobacco products and two studies reported both change in consumption and affordability of tobacco products (Table 2). The majority of the studies reporting inverse association between price and consumption/and affordability of tobacco products have used adjusted odds ratio or marginal coefficient as measures of association between price and outcome variables. Whereas the majority of studies reporting positive or no association between price and consumption/affordability of tobacco products had merely measured the change in frequency of the outcome measure in response to price change (Supplementary file Table S10). Additionally, 
the majority of the studies with inverse association had comprehensively adjusted the socioeconomic variables or adjusted for the cross price elasticity in their analysis. In contrast, only a few studies $(n=5)$ reporting positive or no association had adjusted for socioeconomic or cross price elasticity in their results (Supplementary file Table S11).

\section{The impact of tobacco price/tax on the consumption/affordability of tobacco products}

Among 20 studies reporting the outcome in terms

Table 2. Characteristics of the studies included in the review

\begin{tabular}{|c|c|}
\hline Characteristics & $n$ \\
\hline \multicolumn{2}{|l|}{ Countries (SEAR) } \\
\hline India & 9 \\
\hline Bangladesh & 5 \\
\hline Malaysia & 0 \\
\hline Indonesia & 3 \\
\hline Thailand & 3 \\
\hline Timor-Leste & 0 \\
\hline Myanmar & 2 \\
\hline Democratic Republic of Korea & 0 \\
\hline Nepal & 1 \\
\hline Bhutan & 0 \\
\hline Sri-Lanka & 2 \\
\hline Multi-country (involving more than one SEAR region) & 3 \\
\hline \multicolumn{2}{|l|}{ Study design } \\
\hline Cross-sectional & 3 \\
\hline Case control & 0 \\
\hline Cohort & 0 \\
\hline Secondary quantitative data analysis (or price elasticity) & 25 \\
\hline \multicolumn{2}{|l|}{ Type of tobacco products used } \\
\hline Cigarettes & 13 \\
\hline Bidis & 0 \\
\hline Smokeless tobacco (SLT) & 2 \\
\hline More than one tobacco product (cigarettes, bidis, SLT and others) & 13 \\
\hline \multicolumn{2}{|l|}{ Primary outcome } \\
\hline $\begin{array}{l}\text { Change in consumption (frequency/prevalence) of tobacco } \\
\text { products (primary) }\end{array}$ & 20 \\
\hline Change in affordability of tobacco products (secondary) & 6 \\
\hline Both affordability and consumption as outcomes & 2 \\
\hline \multicolumn{2}{|l|}{ Additional outcomes } \\
\hline Socioeconomic status (SES) analysis & 7 \\
\hline Cross price elasticity & 8 \\
\hline Both SES and product cross price elasticity & 3 \\
\hline
\end{tabular}

of consumption, the majority, i.e. 12 studies, reported an inverse, whilst three reported positive, and two reported no association between price and consumption of tobacco products. The remaining 3 studies reported unclear interpretations on the price response of tobacco products on their consumption. Of 6 studies reporting the outcome in terms of affordability of tobacco products, 2 reported positive association, 3 reported no association, and 1 reported unclear interpretations on the association, between price and affordability of tobacco products (Table 3 and Supplementary file Table S10). The priceelasticity estimates of smokeless tobacco were reported as $-0.59^{32},-0.87^{33}$ and $-0.9^{34}$ in India; and 0.64 to -0.39 in Bangladesh ${ }^{35}$. The price elasticity estimates for cigarettes were reported as: 0.059 to $0.104^{36}$ in Thailand; -0.38 to $-0.19^{33}$ in India; $-0.49^{37}$ in Bangladesh; $-0.02^{38}$ in Indonesia; and $0.36^{39}$ in Myanmar. A detailed account of the findings is given below.

\section{Studies reporting an inverse association between price/tax and consumption/ affordability of tobacco products}

\section{Consumption}

Five studies conducted in India ${ }^{32-34,40,41}$, two in Bangladesh ${ }^{35,37}$ and one each in Nepal ${ }^{42}$, Thailand ${ }^{43}$, Sri Lanka ${ }^{44}$, Myanmar ${ }^{39}$, and Indonesia ${ }^{38}$, reported an inverse association between price and consumption of tobacco products (Table 3 and Supplementary file Table S10). Of the 5 studies in India, two showed an inverse association between price and consumption exclusively for smoking tobacco (cigarettes and bidis $)^{40,41}$, one exclusively for smokeless tobacco ${ }^{34}$, while the remaining two for both smoking and smokeless tobacco products ${ }^{32,33}$. The price elasticity of smokeless tobacco was between -0.09 and -0.87 $(-0.0934,-0.5932$, and -0.8733$)$ while that for smoking tobacco was between -0.27 and -0.92 ; $-0.92^{33}$ and $-0.27^{32}$ for bidis, and $-0.38^{33}$ to $-0.41^{32}$ for cigarettes. A study conducted in Bangladesh, using two waves of ITC survey (2009 and 2010) estimated the cigarette price elasticity to be $-0.49^{37}$. Another study from Bangladesh also using the ITC survey data estimated the price elasticity for smokeless tobacco to be -0.39 to $-0.64^{35}$. Similarly, negative price elasticity estimates for smoking tobacco products were estimated for Nepal (-0.88 for cigarettes and bidis $)^{42}$, 
Table 3. Own price elasticity, consumption and affordability of tobacco products

\begin{tabular}{|c|c|c|c|c|c|c|c|c|}
\hline $\begin{array}{l}\text { Study } \\
\text { number }\end{array}$ & $\begin{array}{l}\text { Study } \\
\text { ID }{ }^{a}\end{array}$ & $\begin{array}{c}\text { First Author a } \\
\text { Year }\end{array}$ & Country & Product & Authors' conclusions & $\begin{array}{c}\text { Measure of } \\
\text { outcome }\end{array}$ & $\begin{array}{l}\text { Relationship } \\
\text { between } \\
\text { price and } \\
\text { consumption/ } \\
\text { affordability }\end{array}$ & Quality \\
\hline 1 & 2 & $\begin{array}{l}\text { Nargis } \\
2019\end{array}$ & Bangladesh & $\begin{array}{l}\text { Cigarettes } \\
\text { and bidis }\end{array}$ & $\begin{array}{l}\text { Few externalities } \\
\text { undermined the } \\
\text { effectiveness of tax and } \\
\text { prices, thereby increasing } \\
\text { cigarette consumption in } \\
\text { Bangladesh }\end{array}$ & Consumption & Positive & High \\
\hline 2 & 3 & $\begin{array}{l}\text { Hussain } \\
2017\end{array}$ & Thailand & Cigarettes & $\begin{array}{l}\text { Overall, no change in } \\
\text { national affordability of } \\
\text { cigarettes }\end{array}$ & $\begin{array}{l}\text { Consumption } \\
\text { and } \\
\text { affordability }\end{array}$ & No & High \\
\hline $3^{*}$ & 4 & $\begin{array}{l}\text { Blecher } \\
2004\end{array}$ & $\begin{array}{l}\text { Sri Lanka, } \\
\text { Thailand, } \\
\text { Bangladesh, } \\
\text { India, } \\
\text { Indonesia }\end{array}$ & Cigarettes & $\begin{array}{l}\text { The average annual } \\
\text { percentage change in RIP } \\
\text { (\%) of cigarettes from 1990- } \\
\text { 2001: i) Sri Lanka: Decrease, } \\
\text { ii) Thailand: Increase, iii) } \\
\text { Bangladesh: Decrease, iv) } \\
\text { India: Decrease, v) Indonesia: } \\
\text { Increase }\end{array}$ & Affordability & Unclear & High \\
\hline 4 & 5 & $\begin{array}{l}\text { Shang } \\
2018\end{array}$ & India & $\begin{array}{l}\text { Cigarettes } \\
\text { and bidis }\end{array}$ & $\begin{array}{l}\text { The cigarette prices were } \\
\text { significantly associated with } \\
\text { lower hazards of smoking } \\
\text { onset** }^{* *} \\
\text { Higher bidi prices were } \\
\text { significantly associated } \\
\text { with a lower hazard of bidi } \\
\text { smoking onset**. }\end{array}$ & Consumption & Inverse & High \\
\hline 5 & 7 & $\begin{array}{l}\text { Kostova } \\
2015\end{array}$ & India & $\begin{array}{l}\text { Smokeless } \\
\text { tobacco }\end{array}$ & $\begin{array}{l}\text { Higher ST prices were found } \\
\text { to reduce ST use at the } \\
\text { intensive margin. }\end{array}$ & Consumption & Inverse & Moderate \\
\hline 6 & 8 & $\begin{array}{l}\text { White } \\
2015\end{array}$ & Thailand & Cigarettes & $\begin{array}{l}\text { Although } 50.1 \% \text { of } \\
\text { all smokers decreased } \\
\text { consumption. The marginal } \\
\text { effects of cigarette prices } \\
\text { on consumption (price } \\
\text { elasticity) were small and of } \\
\text { the wrong sign for two of } \\
\text { four models. It did not alter } \\
\text { the intensity of continuing } \\
\text { smokers. }\end{array}$ & Consumption & $\begin{array}{l}\text { Contradictory } \\
\text { statements } \\
\text { within the } \\
\text { study, hence } \\
\text { unclear }\end{array}$ & High \\
\hline 7 & 11 & $\begin{array}{l}\text { John } \\
2008\end{array}$ & India & $\begin{array}{l}\text { Cigarettes, } \\
\text { bidis } \\
\text { and leaf } \\
\text { tobacco }\end{array}$ & $\begin{array}{l}\text { The proportionate increases } \\
\text { in price lead to slightly } \\
\text { less than proportionate } \\
\text { reductions in consumption } \\
\text { in the case of bidis and leaf } \\
\text { tobacco, while leading to } \\
\text { much less proportionate } \\
\text { reductions in consumption in } \\
\text { the case of cigarettes. }\end{array}$ & Consumption & Inverse & High \\
\hline 8 & 14 & $\begin{array}{l}\text { Zheng } \\
2018\end{array}$ & Indonesia & Cigarettes & $\begin{array}{l}\text { From } 2002 \text { to } 2016 \text {, cigarette } \\
\text { consumption steadily } \\
\text { increased, in association with } \\
\text { an increase in affordability. }\end{array}$ & $\begin{array}{l}\text { Consumption } \\
\text { as well as } \\
\text { affordability }\end{array}$ & Positive & High \\
\hline
\end{tabular}


Table 3. Continued

\begin{tabular}{|c|c|c|c|c|c|c|c|c|}
\hline $\begin{array}{l}\text { Study } \\
\text { number }\end{array}$ & $\begin{array}{l}\text { Study } \\
\text { ID }^{\mathrm{a}}\end{array}$ & $\begin{array}{l}\text { First Author a } \\
\text { Year }\end{array}$ & Country & Product & Authors' conclusions & $\begin{array}{l}\text { Measure of } \\
\text { outcome }\end{array}$ & $\begin{array}{c}\text { Relationship } \\
\text { between } \\
\text { price and } \\
\text { consumption/ } \\
\text { affordability }\end{array}$ & Quality \\
\hline 9 & 20 & $\begin{array}{l}\text { Jha P } \\
2012\end{array}$ & $\begin{array}{l}\text { Thailand and } \\
\text { India }\end{array}$ & Cigarettes & $\begin{array}{l}\text { Although mentioned that } \\
\text { large taxes are an effective } \\
\text { instrument in reducing the } \\
\text { number of smokers but no } \\
\text { clear-cut interpretations } \\
\text { could be drawn on } \\
\text { the impact of price on } \\
\text { consumption. }\end{array}$ & Consumption & Unclear & Moderate \\
\hline 10 & 22 & $\begin{array}{l}\text { Kengganpanich } \\
2009\end{array}$ & Thailand & Cigarettes & $\begin{array}{l}\text { The cigarette consumption } \\
\text { reduced after tax increase. }\end{array}$ & Consumption & Inverse & High \\
\hline 11 & 24 & $\begin{array}{l}\text { Joseph } \\
2013\end{array}$ & India & $\begin{array}{l}\text { Cigarettes, } \\
\text { bidis and } \\
\text { gutka }\end{array}$ & $\begin{array}{l}\text { Based on the price elasticity } \\
\text { estimates calculated in the } \\
\text { study, higher tobacco prices } \\
\text { can be an effective deterrent } \\
\text { in participation among } \\
\text { youth. }\end{array}$ & Consumption & Inverse & High \\
\hline 12 & 26 & $\begin{array}{l}\text { Nargis } \\
2014\end{array}$ & Bangladesh & Cigarettes & $\begin{array}{l}\text { Cigarette price leads to less } \\
\text { than proportionate decrease } \\
\text { in consumption. }\end{array}$ & Consumption & Inverse & High \\
\hline 13 & 28 & $\begin{array}{l}\text { Nargis } \\
2018\end{array}$ & Bangladesh & $\begin{array}{l}\text { Cigarettes, } \\
\text { bidis and } \\
\text { smokeless } \\
\text { tobacco }\end{array}$ & $\begin{array}{l}\text { The affordability of bidis and } \\
\text { cigarettes increased while } \\
\text { SLT remained unchanged. }\end{array}$ & Affordability & $\begin{array}{l}\text { Positive for } \\
\text { bidis and } \\
\text { cigarettes; no } \\
\text { for SLT }\end{array}$ & High \\
\hline 14 & 29 & $\begin{array}{l}\text { John } \\
2020\end{array}$ & India & $\begin{array}{l}\text { Cigarettes, } \\
\text { bidis and } \\
\text { SLT }\end{array}$ & $\begin{array}{l}\text { The overall affordability of } \\
\text { products has increased post } \\
\text { GST. }{ }^{* *}\end{array}$ & $\begin{array}{l}\text { Consumption } \\
\text { and } \\
\text { affordability }\end{array}$ & Unclear & High \\
\hline 15 & 36 & $\begin{array}{l}\text { Huq } \\
2018\end{array}$ & Bangladesh & Cigarettes & $\begin{array}{l}\text { While the top two tiers did } \\
\text { not see any major shift but } \\
\text { the consumption increased } \\
\text { in low and medium tier. }\end{array}$ & Consumption & Positive & High \\
\hline 16 & 37 & $\begin{array}{l}\text { Guindon } \\
2019\end{array}$ & India & $\begin{array}{l}\text { Cigarettes } \\
\text { and bidis }\end{array}$ & $\begin{array}{l}\text { Bidis and cigarettes have } \\
\text { become substantially } \\
\text { affordable, despite the price } \\
\text { increase. }\end{array}$ & Affordability & Positive & High \\
\hline 17 & 39 & $\begin{array}{l}\text { Fernando } \\
2019\end{array}$ & Sri Lanka & Any type & $\begin{array}{l}\text { Increasing the price of } \\
\text { tobacco products has } \\
\text { no significant impact on } \\
\text { smoking behaviors. }\end{array}$ & Consumption & Positive & Low \\
\hline 18 & 45 & $\begin{array}{l}\text { Shang } \\
2017\end{array}$ & India & $\begin{array}{l}\text { Cigarettes, } \\
\text { bidis and } \\
\text { dual }\end{array}$ & $\begin{array}{l}\text { Higher state cigarette } \\
\text { VAT rates in India were } \\
\text { significantly associated with } \\
\text { lower smoking. }\end{array}$ & Consumption & Inverse & High \\
\hline 19 & 46 & $\begin{array}{l}\text { Nargis } \\
2014\end{array}$ & Bangladesh & SLT-zarda & $\begin{array}{l}\text { The price of zarda appears } \\
\text { to influence the prevalence } \\
\text { of zarda use negatively as } \\
\text { expected. }\end{array}$ & Consumption & Inverse & High \\
\hline 20 & 55 & $\begin{array}{l}\text { Arunatilake } \\
2000\end{array}$ & Sri Lanka & $\begin{array}{l}\text { Overall } \\
\text { tobacco }\end{array}$ & $\begin{array}{l}\text { Based on the price elasticity } \\
\text { estimates; price increases are } \\
\text { effective in reducing tobacco } \\
\text { consumption. }\end{array}$ & Consumption & Inverse & High \\
\hline
\end{tabular}


Table 3. Continued

\begin{tabular}{|c|c|c|c|c|c|c|c|c|}
\hline $\begin{array}{l}\text { Study } \\
\text { number }\end{array}$ & $\begin{array}{l}\text { Study } \\
\text { ID }\end{array}$ & $\begin{array}{l}\text { First Author a } \\
\text { Year }\end{array}$ & Country & Product & Authors' conclusions & $\begin{array}{c}\text { Measure of } \\
\text { outcome }\end{array}$ & $\begin{array}{l}\text { Relationship } \\
\text { between } \\
\text { price and } \\
\text { consumption/ } \\
\text { affordability }\end{array}$ & Quality \\
\hline 21 & 66 & $\begin{array}{l}\text { John } \\
2010\end{array}$ & India & $\begin{array}{l}\text { Cigarettes, } \\
\text { bidis and } \\
\text { chewing }\end{array}$ & $\begin{array}{l}\text { All products have become } \\
\text { more affordable (based on } \\
\text { RIP computed for all the } \\
\text { three types). }\end{array}$ & Affordability & Positive & Moderate \\
\hline 22 & 67 & $\begin{array}{l}\text { Report } \\
2014\end{array}$ & $\begin{array}{l}\text { Myanmar, } \\
\text { Indonesia } \\
\text { and Thailand }\end{array}$ & Cigarettes & $\begin{array}{l}\text { No definite answer for } \\
\text { Myanmar. Increased } \\
\text { prevalence for cigarette } \\
\text { smoking in Indonesia. } \\
\text { While for Thailand as taxes } \\
\text { increased, the prevalence } \\
\text { decreased. }\end{array}$ & Consumption & Unclear & Moderate \\
\hline 23 & 69 & $\begin{array}{l}\text { Adioetomo } \\
2005\end{array}$ & Indonesia & Cigarettes & $\begin{array}{l}\text { Price increase will have } \\
\text { effect on quantities of } \\
\text { cigarettes consumed, based } \\
\text { on the negative price } \\
\text { elasticity estimates. }\end{array}$ & Consumption & Inverse & High \\
\hline 24 & 70 & $\begin{array}{l}\text { Yurekli } \\
2003\end{array}$ & Nepal & $\begin{array}{l}\text { Cigarettes } \\
\text { and bidis }\end{array}$ & $\begin{array}{l}\text { Negative price elasticity } \\
\text { estimates; Increase in } \\
\text { excise taxes would reduce } \\
\text { consumption. }\end{array}$ & Consumption & Inverse & High \\
\hline 25 & 71 & $\begin{array}{l}\text { Kyaing NN } \\
2005\end{array}$ & Myanmar & $\begin{array}{l}\text { Cigarettes, } \\
\text { cheroots, } \\
\text { SLT }\end{array}$ & $\begin{array}{l}\text { Based on the price elasticity } \\
\text { estimates higher prices of } \\
\text { tobacco products will lead to } \\
\text { reduced consumption. }\end{array}$ & Consumption & Inverse & High \\
\hline 26 & 72 & $\begin{array}{l}\text { Kyaing } \\
2003\end{array}$ & Myanmar & $\begin{array}{l}\text { All } \\
\text { tobacco } \\
\text { products }\end{array}$ & $\begin{array}{l}\text { Cigarette affordability } \\
\text { did not change much but } \\
\text { cheroots have become much } \\
\text { more affordable. }\end{array}$ & Affordability & $\begin{array}{l}\text { No as well } \\
\text { positive }\end{array}$ & Moderate \\
\hline 27 & 73 & $\begin{array}{l}\text { Djutaharta } \\
2005\end{array}$ & Indonesia & Cigarettes & $\begin{array}{l}\text { Overall, the trend in } \\
\text { cigarette consumption } \\
\text { neither increased or } \\
\text { decreased. }\end{array}$ & Consumption & No & High \\
\hline 28 & 74 & $\begin{array}{l}\text { Goodchild } \\
2020\end{array}$ & India & $\begin{array}{l}\text { Cigarettes, } \\
\text { bidis and } \\
\text { chewing }\end{array}$ & $\begin{array}{l}\text { No significant change } \\
\text { in affordability of bidis } \\
\text { and cigarettes. While } \\
\text { affordability of SLT has } \\
\text { reduced significantly. }\end{array}$ & Affordability & $\begin{array}{l}\text { No as well } \\
\text { positive }\end{array}$ & Moderate \\
\hline
\end{tabular}

a The reference for each Study ID is given in the Supplementary file Table S9. *These interpretations were given in graphs and not explicitly stated by the authors. Hence, no clear inferences could be drawn for findings specific to WHO-SEAR countries. ${ }^{* *}$ In study 5 , onset refers to a created dummy variable and pertains to start of tobacco use in the given year (coded as 1, and 0 for non-smokers). ${ }^{* *}$ The author does say that this is due to no increase in taxation within GST regime, unlike high VAT tax. Note: Although affordability is expressed as RIP (\%) in most of studies, increase in RIP means tobacco products become expensive, however for easy interpretation of results 'direct' relationship between price and affordability of products means that products have become more affordable despite the price increase.

Indonesia (-0.02 for cigarettes) $)^{38}$ and Myanmar (-0.36 for cheroots, and -0.25 for cigarettes $)^{39}$. One study estimated the overall price elasticity for all tobacco products to be -0.53 in Sri Lanka ${ }^{44}$. A cross-sectional telephone survey among 504 daily smokers in Thailand reported that in response to an increase in cigarette excise tax from $80 \%$ to $85 \%, 48 \%$ of the daily smokers reduced their amount of cigarettes smoking ${ }^{43}$. Around $17.3 \%$ and $7.6 \%$ of smokers reduced the number of smoking days and number of cigarettes per day, respectively (Table 3 and Supplementary file Table S10 ${ }^{43}$. 


\section{Affordability}

We did not identify any studies reporting an inverse association between price/tax and affordability of tobacco products.

\section{Studies reporting a positive or no association between price/tax and consumption/ affordability of tobacco products \\ Consumption}

One study each from Thailand ${ }^{45}$, Sri Lanka ${ }^{46}$, Indonesia ${ }^{47}$, and Myanmar ${ }^{48}$, reported positive or no association between price and consumption of tobacco products. In Bangladesh, two studies reported a positive ${ }^{49,50}$ association between price/tax of tobacco products with their consumption.

\section{Affordability}

There were three studies from India that reported no or a positive association between price and affordability of tobacco products (Table 3 and Supplementary file Table S10 $)^{2,23,51}$. One of the studies suggested that smoked (cigarettes and bidis) products became cheaper between 2000 and $2017^{51}$, and another suggested all the tobacco products (cigarettes, bidis, and chewing tobacco) became cheaper between 1996 and 2007, despite the increase in the price of tobacco products ${ }^{2}$. Additionally, one study each in Thailand $^{45}$ and Indonesia ${ }^{52}$ reported direct or no change in the consumption as well as in affordability of tobacco products besides the increase in their price.

\section{Studies with unclear interpretations of the relation between price/tax and consumption/ affordability of tobacco products \\ Consumption}

A study in Thailand ${ }^{36}$, using two panel datasets from ITC surveys (2005 and 2006) to investigate the response of cigarette smokers to an increase in price found that $50 \%$ of the smokers decreased their consumption, but $19.9 \%$ of smokers also increased the intensity of smoking (more than 1\%), despite the price change. Hence, no clear-cut inference could be drawn based on these findings ${ }^{36}$. Another multi-country study (Myanmar, Indonesia, and Thailand) ${ }^{53}$ demonstrated a mixed impact of taxation (as a \% of price) on cigarette consumption. While the author did not explicitly state the results for Myanmar, the findings suggested increased cigarette smoking prevalence in Indonesia and decreased smoking prevalence in Thailand in response to increase in cigarette prices/ taxes (Table 3 and Supplementary file Table S10) ${ }^{53}$. Another two-country study (Thailand and India) ${ }^{54}$, discussed the role of prices and consumption of cigarettes. The study concluded that high prices decrease cigarette consumption. Although the study enlisted the prices and prevalence of smoking for the respective countries, it did not explicitly state/discuss the impact of prices on consumption for the respective countries ${ }^{54}$.

\section{Affordability}

The study conducted by Blecher et al. ${ }^{8}$ reported increased affordability of cigarettes in India, Bangladesh and Sri Lanka, and decreased affordability of cigarettes in Indonesia and Thailand from 1990 to 2001. However, individual price increase for respective countries for the change in affordability were not explicitly stated in the study ${ }^{8}$. Another study conducted in India ${ }^{22}$ reported that tobacco products have become more affordable (i.e. cheaper) after the enactment of the Goods and Services Tax (GST in 2017-2018) when compared to the period where Value Added Tax (VAT) was implemented between 2015-2016, due to no revisions in taxes under the GST regime unlike the VAT regime (Table 3 and Supplementary file Table S10). The authors reported that bidis had become less affordable in the states with lower VAT rates, after the first year of GST implementation, but this reduction in the affordability of bidis was not sustained in the consecutive years due to no revisions in the taxes. The authors did not explicitly state separate values for prices and affordability of products in the VAT and GST period in the analysis. Therefore, no clear-cut inference could be drawn regarding the impact of taxes on the affordability of tobacco products.

\section{The impact of tobacco price/tax on the consumption/affordability of tobacco products} by SES

\section{Consumption}

The studies conducted by Hussain et al. ${ }^{45}$ and Nargis et al. ${ }^{37}$ reported the price response of tobacco products of their consumption by education status. Hussain et al. ${ }^{45}$ reported a higher likelihood of consumption of upper-tier price brands amongst individuals with 
Table 4. Change in own price elasticity, consumption and affordability of tobacco products by SES and cross price elasticity of tobacco products (secondary outcome)

\begin{tabular}{|c|c|c|c|}
\hline $\begin{array}{l}\text { Study } \\
\text { number }\end{array}$ & $\begin{array}{l}\text { Study } \\
\text { ID }^{2}\end{array}$ & $\begin{array}{l}\text { First } \\
\text { Author a } \\
\text { Year }\end{array}$ & Secondary variable reported \\
\hline \multicolumn{4}{|c|}{ Consumption } \\
\hline 1 & 3 & $\begin{array}{l}\text { Hussain } \\
2017\end{array}$ & $\begin{array}{l}\text { Education (completed college or } \\
\text { university, income quintiles) }\end{array}$ \\
\hline 2 & 24 & $\begin{array}{l}\text { Joseph } \\
2013\end{array}$ & $\begin{array}{l}\text { Price elasticity of products based on } \\
\text { income }\end{array}$ \\
\hline 3 & 26 & $\begin{array}{l}\text { Nargis } \\
2014\end{array}$ & $\begin{array}{l}\text { Conditional price elasticity based on } \\
\text { household income }\end{array}$ \\
\hline 4 & 55 & $\begin{array}{l}\text { Arunatilake } \\
2000\end{array}$ & $\begin{array}{l}\text { Conditional price elasticity on SES: } \\
\text { Poorest (1) to Richest (5) Expenditure } \\
\text { groups }\end{array}$ \\
\hline 5 & 69 & $\begin{array}{l}\text { Adioetomo } \\
2005\end{array}$ & $\begin{array}{l}\text { Based on SES (household income): } \\
\text { Total price elasticity } \\
\text { Conditional demand elasticity } \\
\text { Price elasticity of smoking } \\
\text { participation }\end{array}$ \\
\hline 6 & 70 & $\begin{array}{l}\text { Yurekli } \\
2003\end{array}$ & $\begin{array}{l}\text { Price elasticity (PE) on income groups } \\
\text { from Lowest (1) to Highest (4) group }\end{array}$ \\
\hline 7 & 71 & $\begin{array}{l}\text { Kyaing NN } \\
2005\end{array}$ & $\begin{array}{l}\text { Conditional price elasticity based on } \\
\text { income quintiles }\end{array}$ \\
\hline \multicolumn{4}{|c|}{ Affordability } \\
\hline 8 & 28 & $\begin{array}{l}\text { Nargis } \\
2018\end{array}$ & $\begin{array}{l}\text { Association of use post price increase } \\
\text { with SES }\end{array}$ \\
\hline 9 & 37 & $\begin{array}{l}\text { Guindon } \\
2019\end{array}$ & $\begin{array}{l}\text { Affordability (RIP\%) of bidis and } \\
\text { cigarettes based on SES }\end{array}$ \\
\hline
\end{tabular}

Smokers with higher educational level and income show higher odds of consuming upper price-tier brands.

Income is positively associated with participation to tobacco use.

Poorer people are more price-sensitive than the rich

With increase in price of tobacco the per capita consumption of tobacco decreased by highest amount in the middle three SES groups.

The poorest households most likely decrease the quantity of cigarettes consumed in response to a price increase. The lower the income group, the more responsive they are to price increases.

Poorer households were more sensitive to price changes compared to richer households.

The poorest groups are the most sensitive to a price increase.

Cigarettes are more affordable for people from high SES compared with low and moderate SES.

Low-SES households reported paying lower prices than high-SES households, especially in bidis compared to cigarettes.

\begin{tabular}{|c|c|c|c|}
\hline & & & \\
\hline 10 & 2 & $\begin{array}{l}\text { Nargis } \\
2019\end{array}$ & $\begin{array}{l}\text { Cross price elasticity of cigarettes } \\
\text { with bidi and dual smokers between } \\
2009 \text { and } 2017 \text {. }\end{array}$ \\
\hline 11 & 5 & $\begin{array}{l}\text { Shang } \\
2018\end{array}$ & $\begin{array}{l}\text { Cross price-elasticity of cigarettes and } \\
\text { bidis prices with any smoking onset. }\end{array}$ \\
\hline 12 & 7 & $\begin{array}{l}\text { Kostova } \\
2015\end{array}$ & Cross price elasticity of bidi with SLT. \\
\hline 13 & 8 & $\begin{array}{l}\text { White } \\
2015\end{array}$ & $\begin{array}{l}\text { Cross price elasticity with both and } \\
\text { RYO. }\end{array}$ \\
\hline 14 & 11 & $\begin{array}{l}\text { John } \\
2008\end{array}$ & $\begin{array}{l}\text { Cross price elasticity for cigarettes, } \\
\text { bidi and leaf tobacco with each other. }\end{array}$ \\
\hline 15 & 36 & $\begin{array}{l}\text { Huq } \\
2018\end{array}$ & $\begin{array}{l}\text { Cross price elasticity of cigarettes } \\
\text { within different price tiers. }\end{array}$ \\
\hline 16 & 39 & $\begin{array}{l}\text { Fernando } \\
2019\end{array}$ & $\begin{array}{l}\text { Cross price elasticity with alternative } \\
\text { products }(\%)\end{array}$ \\
\hline
\end{tabular}

Despite a relative increase in price of cigarettes relative to bidis, it has driven the migration of bidi smokers to cigarettes.

Bidi prices may have a greater impact on reducing smoking onset than cigarette prices.

The cross price elasticity estimates were imprecise and not statistically significant.

The positive cross price elasticities suggest that both mixed use and RYO tobacco are substitute goods for cigarettes.

Any increase in the price of bidis will have greater effects in reducing consumption of cigarettes as well.

An increase in prices significantly increases the probability of up trading and decreases the probability of down trading. An increase in income increases the probability of up trading and decreases the probability of down trading.

More than $80 \%$ of smokers had not used any alternatives instead of tobacco products after raising the price of tobacco products. 
Table 4. Continued

\begin{tabular}{|c|c|c|c|c|}
\hline $\begin{array}{l}\text { Study } \\
\text { number }\end{array}$ & $\begin{array}{l}\text { Study } \\
\text { ID }^{a}\end{array}$ & $\begin{array}{l}\text { First } \\
\text { Author a } \\
\text { Year }\end{array}$ & Secondary variable reported & Authors' conclusions \\
\hline 17 & 45 & $\begin{array}{l}\text { Shang } \\
2019\end{array}$ & $\begin{array}{l}\text { Cross price elasticity and association } \\
\text { for cigarettes and bidis ( 2009-2010 } \\
\text { and 2012-2013). }\end{array}$ & $\begin{array}{l}\text { Higher cigarette VAT rates were significantly associated } \\
\text { with lower dual use of cigarettes and bidis in GATS. The } \\
\text { corresponding elasticity estimates show that an increase in } \\
\text { cigarette VAT rates was associated with a decrease in dual } \\
\text { use in the TCP data as well GATS data. }\end{array}$ \\
\hline 18 & 46 & $\begin{array}{l}\text { Nargis } \\
2014\end{array}$ & $\begin{array}{l}\text { Cross price elasticity for cigarettes, } \\
\text { bidis and zarda prevalence (in } \\
\text { marginal effect coefficient). }\end{array}$ & $\begin{array}{l}\text { Cigarette price has a positive effect on zarda use } \\
\text { prevalence. However, there may not be any substitutability } \\
\text { between bidi and smokeless tobacco. }\end{array}$ \\
\hline
\end{tabular}

a The reference for each Study ID is given in the Supplementary file Table S9.

higher education level (Table 4 and Supplementary Table S11). Studies conducted by Nargis et al. ${ }^{37}$ and Arunatilake et al. ${ }^{44}$ used household income or expenditure to report the change or associations with consumption of tobacco products. Other studies suggested a higher price sensitivity of tobacco use among poor households or lower SES compared to the rich/higher SES (Table 4 and Supplementary file Table S11).

\section{Affordability}

A study conducted in Bangladesh with data from 2009 to 2015 reported increased affordability of cigarettes among people belonging to higher SES (marginal effect coefficient -2.09, S.E. 0.38) (Supplementary file Table S11 ${ }^{6}$. Another study assessing the trends in affordability of cigarettes and bidis from the year 2000 to 2018 in India, reported that low SES households pay lower prices for bidis in comparison to the high SES households ${ }^{2}$. The study reported an increasing gap in self-reported prices of bidis between high and low SES households, while for cigarettes the selfreported prices for high and low SES were almost similar (Table 4 and Supplementary file Table S11) ${ }^{2}$.

\section{Cross price elasticity and consumption}

Eight studies reported the cross price elasticity or change in consumption of one tobacco product due to the change in the price of another tobacco product (Table 4 and Supplementary file Table S11). Three studies reported the change in consumption of smokeless tobacco due to a change in smoked tobacco prices (cross price elasticity) $)^{34,35,46}$. Some studies also reported changes in cigarette prices leading to a significant shift to other tobacco product consumption $^{35,36,40}$; and vice-versa ${ }^{33,49}$. Three studies reported both the change in consumption and cross price elasticity of tobacco products in their respective finding $\mathrm{s}^{32,40,49}$. A study conducted in Thailand, demonstrated that an increase in the price of manufactured cigarettes increased the likelihood of consumption of hand-rolled cigarettes (RYO) and vice-versa ${ }^{36}$. Another study reported the crossprice elasticity of cigarettes to bidis (i.e. change in bidi consumption in response to cigarette prices) to be -0.091 and -0.455 for urban and rural regions, respectively (Supplementary file Table S11). However, the coefficient for cross price elasticity was small and insignificant ${ }^{33}$. The cross price elasticity often helps in indicating a shift in consumption to substitutes/ complementary products. Besides directly stating the cross price elasticity of tobacco products, few studies also linked the increase in the price of one tobacco product to the shift of tobacco consumers to other tobacco products or brands ${ }^{46,50}$. We, however, do not describe the findings of product shifting/substitution in detail in this study, and limit ourselves to reporting clear findings of cross price elasticity only.

\section{Study quality}

The mean quality score for studies in our review was 7.5. Most $(n=21)$ studies were of high quality; six studies were of moderate quality and only one study was of low quality. There were no major differences in the findings of studies (regarding the impact of tobacco prices on their consumption/affordability) based on the quality of studies. The mean score for quality of studies reporting inverse association, 
direct or no association, and unclear association between price and consumption/affordability of tobacco products, were 7.9, 7, and 7.3, respectively. The detailed scoring for each study is provided in Supplementary file Table S12.

\section{DISCUSSION}

This review found that the majority of the studies examining the impact of price/tax on tobacco product consumption reported an inverse association. This is consistent with what is already known of this relationship, i.e. the true association of cigarette prices/taxes are statistically significant and negative towards cigarette consumption, making tax/ price measures effective in controlling cigarette consumption $^{55}$. Nevertheless, a number of studies also reported positive associations or no association, between price/tax and consumption of tobacco products. The differences in findings might be attributed to the fact that studies showing an inverse association tend to be those that comprehensively adjust for SES variables/cross price elasticity of tobacco products in their analysis, whilst those reporting positive or no association tend not to. The range of price elasticity estimates reported by the studies included in the current review (smokeless tobacco -0.09 to -0.90 and smoking tobacco -0.02 to -0.88) was wide, but includes those reported in the 2003 review (the short-term and long-term price elasticity as -0.50 and -0.70 , respectively) focusing on the SEAR ${ }^{18}$. For affordability, all studies identified reported either a positive/no association or unclear findings.

Tobacco users from lower SES groups were found to be more price-sensitive in comparison to those belonging to more affluent groups. A few studies reported the increase in consumption of one tobacco product in response to the increase in the price of another tobacco product (cross price elasticity). Other studies further linked the cross price elasticity to product or brand shifting as well ${ }^{46,50}$. Therefore, as per our stated secondary outcome in the protocol, we limited ourselves to reporting clear findings of cross price elasticity only.

The existing literature suggests that for tobacco products, the price is an important determinant of consumption/affordability ${ }^{56-59}$. However, while price plays a role in regulating the consumption/ affordability of tobacco products, the per capita income growth of the country can influence this relationship ${ }^{17,59}$. The reported positive associations or lack of association between the price and consumption of tobacco products by some studies conducted in Bangladesh $^{6,37,49}$, Thailand ${ }^{45}$, India ${ }^{2,23}$ and Indonesia ${ }^{47}$ could be due to higher economic growth (and therefore, higher income growth) relative to the increase in tobacco prices in these countries. Further, product-substitution involving switching to cheaper alternatives, and heterogeneity among the tobacco prices along with their complex taxation tiers are also potential reasons for no or positive association between tobacco product prices and consumption ${ }^{12}$. The heterogeneity in prices of tobacco products may incentivize tobacco users to migrate to cheaper alternatives, thereby diluting the impact of an increase in tobacco prices on consumption ${ }^{60,61}$.

The findings of this review indicate that lower SES groups are more price responsive than the higher SES groups, suggesting that tobacco price/tax measures could contribute to addressing tobacco-related health inequalities within and across countries. This is particularly important for tobacco epidemic in the LMICs, where the majority of smokers live and the health and economic burden of tobacco use is greatest, including those in the SEAR.

\section{Implications for policy, practice and research}

Our review supports the use of tobacco tax and price measures as effective tools to address the tobacco epidemic, as well as the socioeconomic discrepancies in tobacco consumption and tobacco-related health and economic burden ${ }^{56-58}$ in the SEAR. However, our findings also suggest that there is a need to increase the tobacco taxes and prices to levels that are sufficient to result in an increase in the real price (and therefore reduce affordability) of tobacco products, in order to reduce consumption. In addition, specific taxes and levying taxes uniformly across all tobacco products, without any exceptions or tiers would help to address shifting to cheaper alternatives/product substitution and tax pass through, and therefore strengthen the effects of tobacco-related fiscal policies ${ }^{62}$. The administrative costs involved in levying and collecting taxes on tobacco are small when compared with the health benefits. Revenue from taxes can be used by governments to fund vital health and other services 
for populations in the region. There are diverse micro as well macro level socioeconomic, geographical, and cultural challenges associated with tobacco epidemic across various countries. However, by focusing on a regional level, our review contributes to a better understanding of what policies countries might need to work together on, and advocate for, collectively to address the cross-country and cross-cultural challenges. Our policy recommendations could also be replicated in other similar regions ${ }^{63}$.

We recommend future SEAR studies on this topic to utilize robust study designs and data analysis approaches that allow for causal inferences, for both affordability and consumption. Studies investigating the relationship between tobacco prices/taxes and their real as well as nominal price is particularly needed. In the present review, we did not identify any study meeting our eligibility criteria for a few of the SEAR countries such as the Democratic Republic of Korea, Timor-Leste, Maldives, and Bhutan. Therefore, more country specific research should be encouraged in order to help to understand both the countryand regional-level impact of tax and price tobacco control measures. The deficiency of comprehensive approaches to measure the impact of tobacco control measures in general as well as across SES is also acknowledged in previous reviews ${ }^{64}$.

\section{Strengths and limitations}

As far as we are aware, this is the first systematic review after the advent of MPOWER strategies, to examine the price/tax response of all the tobacco products (smoking and smokeless tobacco) on their consumption/affordability in countries of SEAR. We have drawn our interpretations based on the studies conducted in this region, without any limitation on the year. We have also disaggregated the impact of prices/taxes on consumption/affordability by SES indicators. The study has certain limitations. Due to the limited number of studies and wide heterogeneity across the studies in terms of their intervention as well as reporting of outcomes, we were unable to conduct a meta-analysis. Although we have mentioned the given price/tax estimates for each study in the Supplementary file, we could not present the impact of taxes on real or nominal price of tobacco products. There was no major difference in the change in affordability/price elasticity estimates within studies for smoking and smokeless tobacco. Hence, we did not present estimates separately for smokeless and smoking tobacco products. However, the tables in the Results section do present the estimates separately for each product (cigarettes, bidis, smokeless or other) from the respective studies. The majority of studies in the review were retrospective in design, drawing estimates from previous datasets such as the GATS, TCP, ITC, etc. Although such studies encompassed large populations, the outcome estimates derived from them can vary in survey designs, sampling methods, populations as well country specific differences.

\section{CONCLUSIONS}

The majority of included studies examining the impact of price/tax on tobacco product consumption report an inverse association, thereby supporting the use of tobacco tax and price measures as effective tools to address the tobacco epidemic. Our findings, however, also emphasize the importance of increasing tobacco product taxes and prices sufficiently to outweigh the effects of income growth, in order for the measures to be effective in reducing the affordability and consumption of tobacco products. The availability of cheaper alternatives (often due to tiered and complex taxation systems) can also undermine the effect of fiscal policies in tobacco control. These should be considered when designing future tobacco tax policies in the region.

\section{REFERENCES}

1. Nargis N, Stoklosa M, Shang C, Drope J. Price, Income, and Affordability as the Determinants of Tobacco Consumption: A Practitioner's Guide to Tobacco Taxation. Nicotine Tob Res. 2021;23(1):40-47. doi:10.1093/ntr/ ntaa134

2. Guindon GE, Fatima T, Li DX, et al. Visualizing data: Trends in smoking tobacco prices and taxes in India. Gates Open Res. 2019;3:8. doi:10.12688/gatesopenres.12894.1

3. Guindon GE, Paraje GR, Chaloupka FJ. The Impact of Prices and Taxes on the Use of Tobacco Products in Latin America and the Caribbean. Am J Public Health. 2018;108(Suppl 6):S492-S502. doi:10.2105/AJPH.2014.302396r

4. Jawad M, Lee JT, Glantz S, Millett C. Price elasticity of demand of non-cigarette tobacco products: A systematic review and meta-analysis. Tob Control. 2018;27(6):689695. doi:10.1136/tobaccocontrol-2017-054056

5. Kostova D, Ross H, Blecher E, Markowitz S. Is youth smoking responsive to cigarette prices? Evidence 
from low-and middle-income countries. Tob Control. 2011;20(6):419-424. doi:10.1136/tc.2010.038786

6. Nargis N, Stoklosa M, Drope J, et al. Trend in the affordability of tobacco products in Bangladesh: Findings from the ITC Bangladesh Surveys. Tob Control. $2019 ; 28$ (Suppl 1):S20-S 30 . doi:10.1136/tobaccocontrol-2017-054035

7. Wonderling D, Gruen R, Black N. Introduction to Health Economics. London School of Hygiene and Tropical Medicine; 2005. Understanding Public Health. Black $\mathrm{N}$, Raine R, London School of Hygiene and Tropical Medicine, eds.

8. Blecher EH, van Walbeek CP. An international analysis of cigarette affordability. Tob Control. 2004;13(4):339-346. doi:10.1136/tc.2003.006726

9. Chaloupka FJ, Drope J, Siu E, et al. Tobacconomics: Cigarette Tax Scorecard. Health Policy Center, Institute for Health Research and Policy, University of Illinois Chicago; 2020. Accessed February 25, 2021. https:// tobacconomics.org/files/research/636/uic-tobaccoscorecard-report-eng-v7.1.pdf

10. Harper S, McKinnon B. Global socioeconomic inequalities in tobacco use: internationally comparable estimates from the World Health Surveys. Cancer Causes Control. 2012;23 Suppl 1:11-25. doi:10.1007/s10552-012-9901-5

11. Kyaing NN, Islam MA, Sinha DN, Rinchen S. Social, economic and legal dimensions of tobacco and its control in South-East Asia region. Indian J Public Health. 2011;55(3):161-168. doi:10.4103/0019-557X.89944

12. John RM, Yadav A, Sinha DN. Smokeless tobacco taxation: Lessons from Southeast Asia. Indian J Med Res. 2018;148(1):46-55. doi:10.4103/ijmr.IJMR_1822_17

13. Sreeramareddy CT, Harper S, Ernstsen L. Educational and wealth inequalities in tobacco use among men and women in 54 low-income and middleincome countries. Tob Control. 2018;27(1):26-34. doi:10.1136/tobaccocontrol-2016-053266

14. Thakur JS, Prinja S, Bhatnagar N, Rana S, Sinha DN. Socioeconomic inequality in the prevalence of smoking and smokeless tobacco use in India. Asian Pac J Cancer Prev. 2013;14(11):6965-6969. doi:10.7314/apjcp.2013.14.11.6965

15. Sreeramareddy CT, Pradhan PM, Mir IA, Sin S. Smoking and smokeless tobacco use in nine South and Southeast Asian countries: prevalence estimates and social determinants from Demographic and Health Surveys. Popul Health Metr. 2014;12:22. doi:10.1186/s12963014-00220

16. Kuhonta EM. The Politics of Inequality in Southeast Asia: A Comparative- Historical Perspective. Global Asia. 2016;11. Accessed September 29, 2021. https:// globalasia.org/v11no2/cover/the-politics-of-inequalityin-southeast-asia-a-comparative--historical-perspective_ erik-martinez-kuhonta

17. World Health Organization. WHO Report on the Global
Tobacco Epidemic, 2019. World Health Organization; 2019. Accessed January 4, 2021. https://www.who.int/ teams/health-promotion/tobacco-control/who-report-onthe-global-tobacco-epidemic-2019

18. Guindon GE, Perucic AM, Boisclair D. Higher Tobacco Prices and Taxes in Southeast Asia: An Effective Tool to Reduce Tobacco Use, Save Lives and Generate Revenue. Health, Nutrition and Population (HNP) Discussion Paper. The World Bank; 2003. Accessed September 29, 2021. https://openknowledge.worldbank.org/ bitstreamhandle/10986/13717/288730Guindon 1 Higher0Tobacco1 whole.pdf? sequence $=1 \&$ cisAllowed $=y$

19. Guindon GE, Paraje GR, Chaloupka FJ. The impact of prices and taxes on the use of tobacco products in Latin America and the Caribbean. Am J Public Health. 2015;105(3):e9-e19. doi:10.2105/AJPH.2014.302396

20. Contreary KA, Chattopadhyay SK, Hopkins DP, et al. Economic Impact of Tobacco Price Increases Through Taxation: A Community Guide Systematic Review. Am J Prev Med. 2015;49(5):800-808. doi:10.1016/j.amepre.2015.04.026

21. Krishnamoorthy Y, Majella MG, Murali S. Impact of tobacco industry pricing and marketing strategy on brand choice, loyalty and cessation in global south countries: a systematic review. Int J Public Health. 2020;65(7):10571066. doi:10.1007/s00038-020-01422-2

22. John RM, Dauchy E. Trends in affordability of tobacco products before and after the transition to GST in India. Tob Control. 2020;30. doi:10.1136/tobaccocontrol-2019-055525

23. John MR, Rao K, Rao MG, et al. The Economics of Tobacco and Tobacco Taxation in India. Accessed December 24, 2020. https://tobacconomics.org/research/ the-economics-of-tobacco-and-tobacco-taxation-in-india/

24. Higgins JPT, Thomas J, Chandler J, et al, eds. Cochrane Handbook for Systematic Reviews of Interventions version 6.2. Cochrane; 2021. Updated February 2021. Accessed September 29, 2021. www.training.cochrane. org/handbook

25. Moher D, Liberati A, Tetzlaff J, Altman DG, et al. Preferred reporting items for systematic reviews and meta-analyses: the PRISMA statement. PLoS Med. 2009;6(7):e1000097. doi:10.1371/journal.pmed.1000097

26. Nazar GP, Chugh A, Sharma N, et al. Impact of tobacco price and taxation on affordability and consumption of tobacco products in Southeast Asia Region: a systematic review. 2020. PROSPERO CRD42020133082. Accessed September 29, 2021. https://www.crd.york.ac.uk/ prospero/display_record.php?ID=CRD42020133082

27. Mendeley Reference Manager for Desktop. Mendeley Ltd.; 2021. Accessed September 29, 2021. https://www. mendeley.com/download

28. Cochrane Developmental, Psychosocial and Learning Problems. Data Extraction Forms. Accessed December 23, 2020. https://dplp.cochrane.org/data-extraction-forms 
29. Crombie IK. Pocket Guide to Critical Appraisal. John Wiley \& Sons, Inc; 1996. Accessed December 7, 2020. https:// www.wiley.com/en-ad/Pocket+Guide+to+Critical+ Appraisal-p-9780727910998

30. Steele E, Bialocerkowski A, Grimmer K. The postural effects of load carriage on young people - a systematic review. BMC Musculoskeletal Disorders. 2003;4. doi:10.1186/1471-2474-4-12

31. Popay J, Roberts H, Sowden A, et al. Guidance on the Conduct of Narrative Synthesis in Systematic Reviews: A Product from the ESRC Methods Programme. 2006. Accessed September 29, 2021. https://www.lancaster. ac.uk/media/lancaster-university/content-assets / documents/fhm/dhr/chir/NSsynthesisguidanceVersion1April2006.pdf

32. Joseph RA, Chaloupka FJ. The influence of prices on youth tobacco use in India. Nicotine Tob Res. 2014;16 Suppl 1:S24-S29. doi:10.1093/ntr/ntt041

33. John RM. Price elasticity estimates for tobacco products in India. Health Policy Plan. 2008;23(3):200-209. doi:10.1093/heapol/czn007

34. Kostova D, Dave D. Smokeless tobacco use in India: Role of prices and advertising. Soc Sci Med. 2015;138:82-90. doi:10.1016/j.socscimed.2015.05.036

35. Nargis N, Hussain AK, Fong GT. Smokeless tobacco product prices and taxation in Bangladesh: findings from the International Tobacco Control Survey. Indian J Cancer. 2014;51 Suppl 1(0 1):S33-S38. doi:10.4103/0019-509X.147452

36. White JS, Ross H. Smokers' strategic responses to sin taxes: Evidence from panel data in Thailand. Health Econ. 2015;24(2):127-141. doi:10.1002/hec.3004

37. Nargis N, Ruthbah UH, Hussain AK, Fong GT, Huq I, Ashiquzzaman SM. The price sensitivity of cigarette consumption in Bangladesh: evidence from the International Tobacco Control (ITG) Bangladesh Wave 1 (2009) and Wave 2 (2010) Surveys. Tob Control. 2014;23 Suppl 1(0 1):i39-i47. doi:10.1136/ tobaccocontrol-2012-050835

38. Adioetomo SM, Djutaharta T, Hendratno. Cigarette Consumption, Taxation, and Household Income: Indonesia Case Study. Health, Nutrition and Population (HNP) discussion paper. The World Bank; 2005. Accessed September 29, 2021. https://openknowledge.worldbank. org/bitstream/handle/10986/13737/317960HNP0 Adio 1 eConsumption 01 publc1.pdf? sequence $=1$ \&cisAllowed $=\mathrm{y}$

39. Kyaing NN, Perucic AM, Rahman K. Study on Poverty Alleviation and Tobacco Control in Myanmar. Health, Nutrition and Population (HNP) Discussion Paper. World Bank; 2005. Accessed September 29, 2021. https://openknowledge.worldbank.org/bitstream/ handle/10986/13757/339840MY0Tobacco. pdf? sequence $=1 \&$ isAllowed $=y$

40. Shang C, Chaloupka FJ, Gupta PC, Pednekar MS, Fong
GT. Association between tobacco prices and smoking onset: Evidence from the TCP India Survey. Tob Control. 2019;28:s3-s8. doi:10.1136/tobaccocontrol-2017-054178

41. Shang C, Chaloupka FJ, Fong GT, Gupta PC, Pednekar MS. The Association Between State Value-Added Taxes and Tobacco Use in India-Evidence From GATS and TCP India Survey. Nicotine Tob Res. 2018;20(11):1344-1352. doi:10.1093/ntr/ntx184

42. Karki YB, Pant KD, Pande BR. A Study on the Economics of Tobacco in Nepal. Health, Nutrition and Population (HNP) Discussion Paper. World Bank; 2003. Accessed September 29, 2021. https://openknowledge.worldbank.org/bitstream/ handle/10986/13750/288870Karki1A0Study1whole. pdf? sequence $=1 \&$ is Allowed $=y$

43. Kengganpanich M, Termsirikulchai L, Benjakul S. The impact of cigarette tax increase on smoking behavior of daily smokers. J Med Assoc Thai. 2009;92 Suppl 7:S4653. Accessed September 29, 2021. https://pubmed.ncbi. nlm.nih.gov/20232561/

44. Arunatilake N, Opatha M. The Economics of Tobacco in Sri Lanka. Health, Nutrition and Population (HNP) Discussion Paper. World Bank; 2003. Accessed December 23, 2020. https://openknowledge.worldbank.org/ bitstream/handle/10986/13625/288570Arunatilake1 The0Economics 1 whole.pdf? sequence $=1 \&$ isAllowed $=y$

45. Husain MJ, Kostova D, Mbulo L, Benjakul S, Kengganpanich M, Andes L. Changes in cigarette prices, affordability, and brand-tier consumption after a tobacco tax increase in Thailand: Evidence from the Global Adult Tobacco Surveys, 2009 and 2011. Prev Med. 2017;105S:S4-S9. doi:10.1016/j.ypmed.2017.05.027

46. Fernando HN, Wimaladasa ITP, Sathkoralage AN, et al. Socioeconomic factors associated with tobacco smoking among adult males in Sri Lanka. BMC Public Health. 2019;19(1):778. doi:10.1186/s12889-019-7147-9.

47. Djutaharta T, Viriya Surya H, Pasay NHA, Hendratno, Adioetomo SM. Aggregate Analysis of the Impact of Cigarette Tax Rate Increases on Tobacco Consumption and Government Revenue: The Case of Indonesia. Health, Nutrition and Population (HNP) discussion paper. The World Bank; 2005. Accessed September 29, 2021. https:// openknowledge.worldbank.org/handle/10986/13758

48. Kyaing NN. Tobacco Economics in Myanmar. Health, Nutrition and Population (HNP) Discussion Paper. World Bank; 2003. Accessed September 29, 2021. https:// openknowledge.worldbank.org/bitstream/handle/10 $986 / 13633 / 288900 \mathrm{~K}$ y ing 1 Tobacco 1 whole. pdf? sequence $=1 \&$ isAllowed $=y$

49. Nargis N, Hussain AG, Goodchild M, Quah AC, Fong GT. A decade of cigarette taxation in Bangladesh: lessons learnt for tobacco control. Bull World Health Organ. 2019;97(3):221-229. doi:10.2471/BLT.18.216135

50. Huq I, Nargis N, Lkhagvasuren D, Hussain AG, Fong GT. The Impact of Income and Taxation in a Price- 
Tiered Cigarette Market: Findings from the ITC Bangladesh Surveys. Tob Control. 2019;28:s37-s44. doi:10.1136/tobaccocontrol-2017-054053

51. Goodchild M, Sinha P, Gill Munish V, Tullu FT. Changes in the affordability of tobacco products in India during 2007/2008 to 2017/2018: a price-relative-to-income analysis. WHO South East Asia J Public Health. 2020;9(1):73-81. Accessed September 29, 2021. https:// apps.who.int/iris/bitstream/handle/10665/331836/ whoseajph2020v9i1p73.pdf?sequence $=1 \&$ isAllowed $=y$

52. Zheng R, Marquez PV, Ahsan A, Wang Y, Hu X. Cigarette affordability in Indonesia: 2002-2017. The World Bank; 2018. Accessed September 29, 2021. https://openknowledge.worldbank.org/bitstream/ handle/10986/30027/126585-WP-PUBLIC-P154568WBGCigaretteAffordabilityIndonesiaFinalweb. pdf? sequence $=1 \&$ isAllowed $=y$

53. Southeast Asia Initiative on Tobacco Tax (SITT) of the Southeast Asia Tobacco Control Alliance (SEATCA) ASEAN. Accessed December 23, 2020. www.seatca.org.

54. Jha P, Joseph R, Li D, et al. Tobacco Taxes: A Win-Win Measure for Fiscal Space and Health. University of Washington; 2018. Accessed September 29, 2021. http:// $\mathrm{dcp}$-3.org/resources/tobacco-taxes-win-win-measurefiscal-space-and-health

55. Chaloupka FJ, Powell LM, Warner KE. The Use of Excise Taxes to Reduce Tobacco, Alcohol, and Sugary Beverage Consumption. Annu Rev Public Health. 2019;40:187-201. doi:10.1146/annurev-publhealth-040218-043816

56. World Health Organization. Tobacco-Free Initiative: Taxation. Accessed January 3, 2021. https://www.who. int/tobacco/economics/taxation/en/

57. Hill S, Amos A, Clifford D, Platt S. Impact of tobacco control interventions on socioeconomic inequalities in smoking: Review of the evidence. Tob Control. 2014;23(e2):e89-e97. doi:10.1136/ tobaccocontrol-2013-051110

58. Brown T, Platt S, Amos A. Equity impact of interventions and policies to reduce smoking in youth: Systematic review. Tob Control. 2014;23(e2):e98-e105. doi:10.1136/tobaccocontrol-2013-051451

59. He Y, Shang C, Chaloupka FJ. The association between cigarette affordability and consumption: An update. PLoS One. 2018;13(12):e0200665. doi:10.1371/journal. pone. 0200665

60. Burguillo M, Romero-Jordán D, Sanz-Sanz JF. Efficacy of the tobacco tax policy in the presence of product heterogeneity: A pseudo-panel approach applied to Spain. Health Policy. 2019;123(10):924-931. doi:10.1016/j.healthpol.2019.06.011

61. Da Pra M, Arnade CA. Tobacco product demand, cigarette taxes, and market substitution. Paper presented at: Agricultural \& Applied Economics Association and American Council on Consumer Interests; July 26-28, 2009; Madison, Wisconsin. doi:10.22004/ag.econ.49210
62. Prasetyo BW, Adrison V. Cigarette prices in a complex cigarette tax system: empirical evidence from Indonesia. Tob Control. 2020;29:618-623. doi:10.1136/tobaccocontrol-2018-054872

63. Berg CJ, Fong GT, Thrasher JF, et al. The impact and relevance of tobacco control research in low-and middleincome countries globally and to the US. Addict Behav. 2018;87:162-168. doi:10.1016/j.addbeh.2018.07.012

64. Smith CE, Hill SE, Amos A. Impact of population tobacco control interventions on socioeconomic inequalities in smoking: a systematic review and appraisal of future research directions. Tob Control. 2020. doi:10.1136/tobaccocontrol-2020-055874

\section{CONFLICTS OF INTEREST}

The authors have each completed and submitted an ICMJE form for disclosure of potential conflicts of interest. The authors declare that they have no competing interests, financial or otherwise, related to the current work. All the authors report that since the initial planning of the work and in the past 36 months this research was completed as part of the Tobacco Control Capacity program and it was supported by UKRI Global Challenges Research Fund (MR/P027946/2).

\section{FUNDING}

This research was completed as part of the Tobacco Control Capacity program. This work was supported by UKRI Global Challenges Research Fund (MR/P027946/2). The Tobacco Control Capacity program is a capacity development and research coordinated by the University of Edinburgh, Scotland, and involves 15 partner institutions from Africa, South Asia and the United Kingdom.

ETHICAL APPROVAL AND INFORMED CONSENT

Ethical approval and informed consent were not required for this review.

\section{DATA AVAILABILITY}

The data supporting this research can be found in the Supplementary file.

\section{AUTHORS' CONTRIBUTIONS}

GPN, MA, RH and NDM were involved in the concept and design of the study. NS, SL and AC contributed to literature searches. LB and MA secured funding for the study. NS and SMA contributed to data extraction. AC, SMA and GPN contributed to the critical appraisal of studies. GPN and NS contributed to data synthesis. GPN, NS and AC prepared the first draft of the manuscript. GPN, MA, RH, SMA, NDM, RMJ and LB reviewed the manuscript critically for intellectual content. All authors approved the final version of the manuscript submitted.

\section{PROVENANCE AND PEER REVIEW}

Not commissioned; externally peer reviewed. 